\title{
Scleredema Diabeticorum Partially Treated with Low-Dose Methotrexate: a Report of Five Cases
}

\author{
Asena Çiğdem Doğramacı ${ }^{1}$, Mehmet Uğur İnan¹, Esin Atik², Cumali Gökçe \\ 'Department of Dermatology, Faculty of Medicine, Mustafa Kemal University, Hatay, Turkey \\ ${ }^{2}$ Department of Pathology, Faculty of Medicine, Mustafa Kemal University, Hatay, Turkey \\ ${ }^{3}$ Department of Internal Medicine, Faculty of Medicine, Mustafa Kemal University, Hatay, Turkey
}

\begin{abstract}
Scleredema is a rare connective tissue disorder that belongs to a group of scleroderma-like disorders. Although no known curative therapy exists, various specific treatments have been proposed in the literature. In this report, we describe five cases of scleredema partially treated with low-dose methotrexate therapy. All patients have diabetes mellitus type II. All patients were started on methotrexate 15 mg subcutaneously once weekly for 3 months. Biopsy specimens were taken from all patients and were examinated histologically before the treatment and after 3 months of treatment. All cases partially responded to low-dose methotrexate therapy. We believe that methotrexate therapy may be an alternative therapeutic options in scleredema in view of its efficacy.
\end{abstract}

Key word: Scleredema, low-dose methotrexate, diabetes mellitus

Received: 26.07.2011 Accepted: 12.10.2011

\section{Introduction}

Scleredema is a rare connective tissue disorder, with an unclear pathogenetic mechanism. It is characterized by diffuse, nonpitting swelling and induration of the skin that typically begins in the neck and spreads to the face, scalp, shoulders, and trunk. The hands and feet are characteristically spared $(1,2)$. Three types of scleredema are differentiated. Type 1 is usually preceded by a febrile episode and resolves spontaneously. Type 2 is associated with developing paraproteinemias including multiple myeloma. Type 3 is associated with diabetes mellitus, so-called scleredema diabeticorum $(2,3)$. Many therapies, including ultraviolet (UV) A1 phototherapy, bath psoralen UVA, extracorporeal photopheresis, radiation, electron beam, prostaglandin E1, cyclosporine and high-dose penicillin have been used with varying degrees of success in separate case reports $(4,5)$. There are some conflicting data about treatment success of low dose-methotrexate (MTX) regimen in scleredema in the literature $(6,7)$.

Herein we report five cases of scleredema. It is remarkable that all the cases were diagnosed as type II diabetes mellitus. All cases showed partial clinical and histopathological improvement with low-dose MTX therapy without obvious side effects. We examined the efficacy of low-dose MTX treatment by evaluating biopsy specimens histologically.

\section{Cases}

\section{Case 1}

A 40-year-old man presented with acneiform lesions on the back of his neck. His medical history was unremarkable. On his dermatological examination, in addition to some acneiform papules on his neck, diffuse hardening of the skin of the back of his neck and upper back were noticed (Figure 1). There was no involvement of the hands or lower extremities. The patient was unaware of this abnormality. His laboratory evaluation revealed a blood glucose level of $303 \mathrm{mg} / \mathrm{dL}$ and hemoglobin A1C level of $8.0 \%$. A biopsy specimen from the skin of his back showed a thickened dermis with thickened collagen bundles separated by clear spaces with Alcian bluestaining mucin deposition (Figure 2,3). With these findings the diagnoses of scleredema, acne keloidalis and type II diabetes mellitus were made at the same time.

\section{Case 2}

A 56-year-old woman presented to our dermatology outpatient clinic for evaluation of possible scleredema. She had a 2-year history of tightness, thickening, and hardening of the skin on her back which had slowly worsened with time. She had had diabetes mellitus type II for 15 years and she had been using insulin. She also had chronic renal failure due to uncontrolled hypertension, and had been on hemodialysis three times a week for 5 years (Figure 4). 


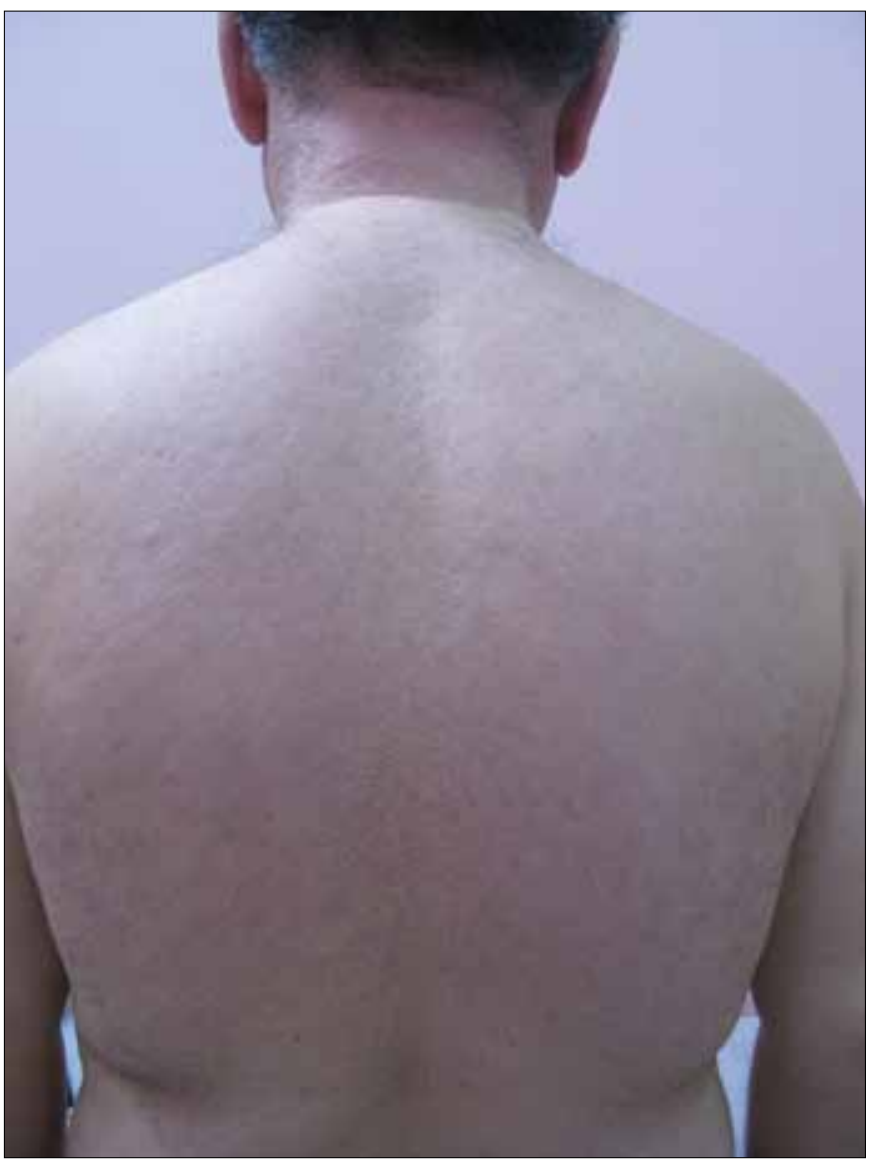

Figure 1. Severe thickening of the skin of the neck and back in Case 1

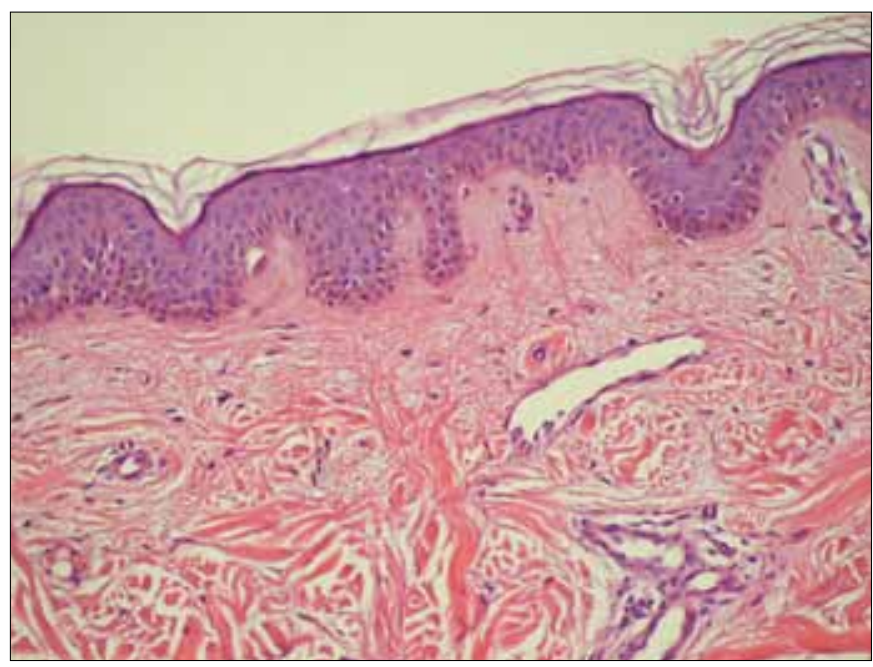

Figure 2. Biopsy specimens from the upper back of the Case 1 demonstrate the edematous changes seen with scleredema. In the dermis, there are abundant thickened collagen bundles separated by clear spaces. The collagen fibers are also irregularly arranged (H\&E, original magnification $\times 100)$

\section{Case 3}

A 57-year-old woman presented to our clinic complaining of tightness in her back. She had a 3-year history of thickening of her back which had slowly spreading to her neck and arms.

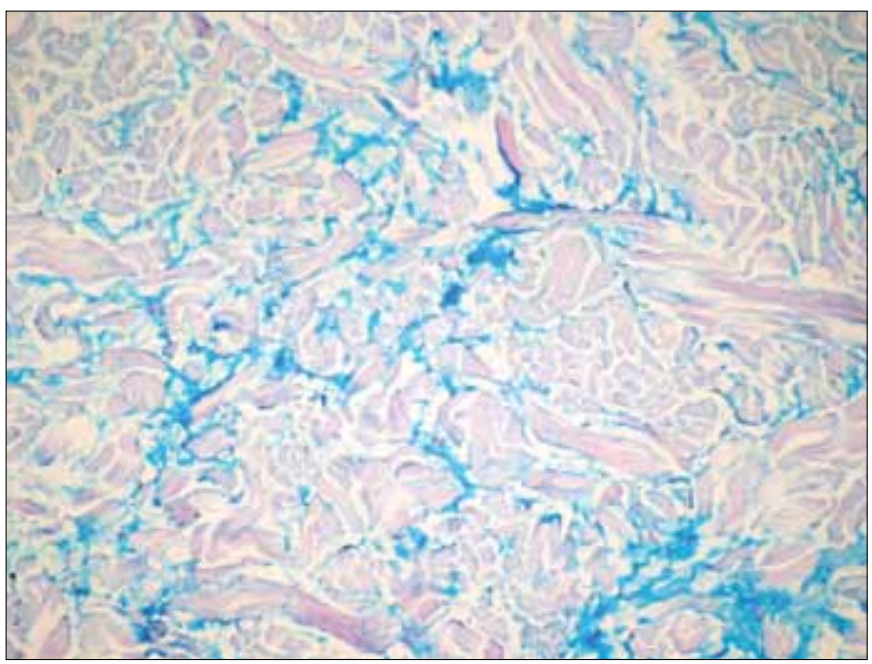

Figure 3. Deposits of mucin within the dermis (original magnification x200, Alcian blue)

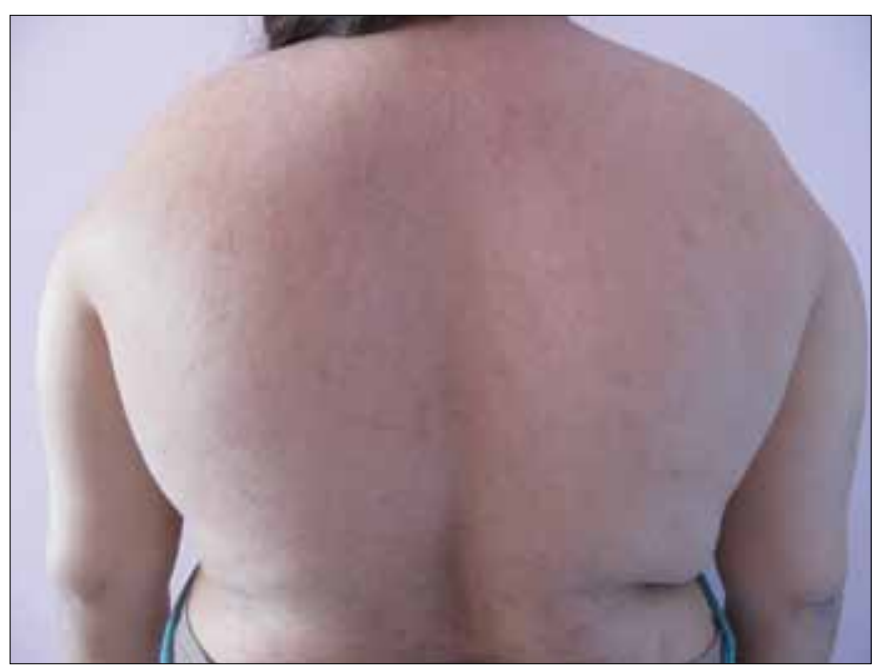

Figure 4. Severe thickening of the skin of the neck, back and upper arms in Case 2

She had had diabetes mellitus type II for eleven years but was using her insulin as irregular.

\section{Case 4}

A 52-year-old woman had a 3 year history of progressive tightness and thickening of the skin in the neck and shoulder region. She had been treated with PUVA therapy for 1.5 years in a different dermatology clinic with the diagnosis of morphea 2 years previously. She had had diabetes mellitus type II for 10 years.

\section{Case 5}

A 74-year-old woman was referred from the endocrinology clinic for tightness on her neck and back since she was 64 . She had had diabetes mellitus type II for 25 years and she had been using insulin and oral antidiabetics.

Based on the findings of clinical and histological examination of all the cases, a diagnosis of scleredema diabeticorum was made. The characteristics of patients were demonstrated 
in Table 1. Screening for monoclonal gammapathy was unremarkable in all cases. None of the patients had eosinophilia or Raynaud's phenomenon. Antinuclear, antidouble-stranded DNA antibodies, rheumatoid factor, and Scl-70 were not demonstrable. The serology for Borrelia burgdorferi showed no evidence of infection. No preceding acute infections were found.

All patients were started on MTX $15 \mathrm{mg}$ subcutaneously once weekly, followed by $1 \mathrm{mg} /$ day folic acid on the other six days. After three months of the therapy, there was a moderate reduction in the degree of skin thickness, a softening of the skin and a marked improvement in range of motions in all cases. Control biopsies obtained from all of the patients after three months of therapy were compared to their pretreatment biopsies. There was substantial edematous regression and moderate decrease of collagen bundles after the treatment. There were no obvious adverse effects of MTX. A control biopsy of case 1 was shown in Figure 5.

\section{Discussion}

The exact pathophysiology of scleredema and the scleroderma-like syndrome has not been fully elucidated. The accumulation of the extra cellular matrix components seems to be represented by an abnormal expression of extracelluler protein genes in the skin rather than a decrease of clearing processes (8). This gene dysregulation is observed in scleredema

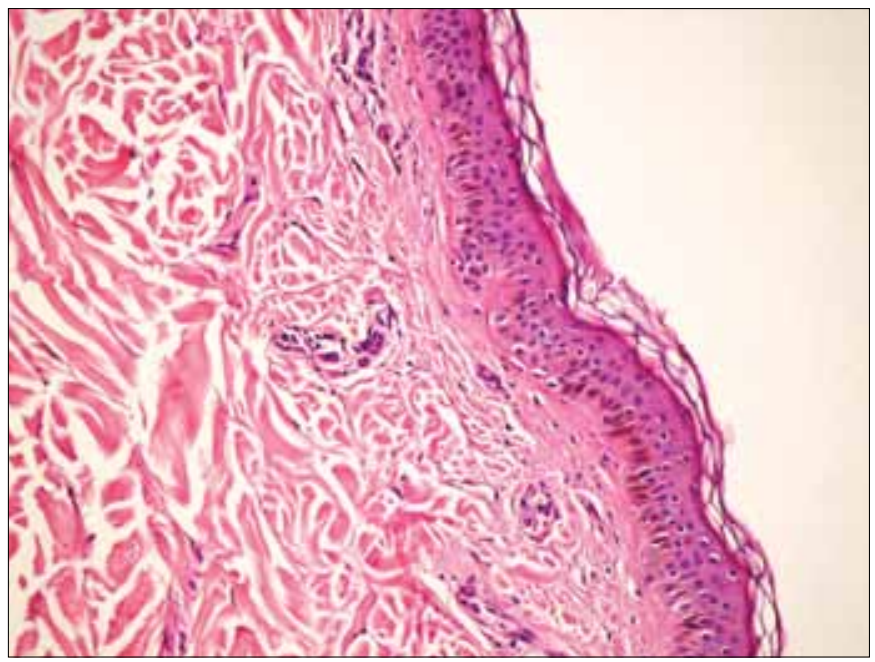

Figure 5. A posttreatment control biopsy of Case 1. There is susbtantial edematous regression and a moderate decrease of collagen bundles (H\&E original magnification $\times 100$ ) regardless of the presence of diabetes. A nonenzymatic glycosylation process due to peripheral hyperglycemia might represent the underlying pathogenicity even of aberrant collagen formation. Diabetes is observed in half the cases of scleredema $(9,10)$. Scleredema has been observed in patients suffering from either type 1 or type 2 diabetes mellitus, even if type 2 diabetes seems to be largely more frequent. Duration of diabetes and poor metabolic control were risk factors for the scleredema diabeticorum. Indeed, our first case was unaware of his diabetes and we did not have any information about the duration of his diabetes. Scleredema may be associated with systemic diseases such as multiple myeloma, hyperparathyroidism, malignant insulinoma, Gougerot-Sjögren syndrome or rheumatoid arthritis in the rare large series published in the literature $(11,12)$. Although we examined all our five cases in the laboratuary assays, we did not observe any finding related with paraproteinemias or the other above-mentioned systemic diseases.

The diagnosis of scleredema is based on clinical presentation. Histological confirmation is usually not required. On skin biopsy, the epidermis is generally not involved. The dermis tends to be thickened and may be up to four times thicker than a normal dermis The collagen fibers appear swollen and are separated by wide spaces. The subcutaneous tissue is also involved, with fat being replaced by coarse collagen fibers. Mucin deposit is more likely to be observed in the deep dermis and can be stained with Alcian Blue dye $(1,13)$. In biopsy specimens, we observed enlarged and thickened collagen bundles within the reticular dermis and increased connective tissue mucin deposits. When the pretherapeutic and posttherapeutic biopsy specimens were examined, we observed that there was substantial edematous regression and a moderate decrease of collagen bundles after the treatment.

Some eosinophilic syndromes can also cause skin sclerosis. Diffuse fasciitis with eosinophilia (also called eosinophilic fasciitis or Shulman's syndrome) is a rare condition that mimics scleredema, with swelling, stiffness, and decreased flexibility of the limbs associated with skin thickening. In addition, there is no occurrence of Raynaud's or Gl involvement. Eosinophiliamyalgia syndrome and toxic oil syndrome are toxin-induced disorders that also mimic scleredema. Both conditions result in skin fibrosis and can become chronic. Hypereosinophilia is frequently seen in all these conditions.

Although various specific treatments are proposed in the literature, treatment modalities are not completely curative. Numerous therapies have been tried, including pituitary extract, thyroid hormones, immunosuppressants, antibiotics, corticosteroids, and physiotherapy; however, none has prov-

Table 1. Characteristics of patients

\begin{tabular}{|lcccc|}
\hline Patient & Age & Sex & Duration of diabetes & Site of involvement \\
\hline 1 & 40 & Male & New diagnosis & Posterior back, upper neck \\
2 & 56 & Female & 15 years & Back \\
3 & 57 & Female & 11 years & Back \\
4 & 52 & Female & 10 years & Back and neck \\
5 & 74 & Female & 25 years & Back and neck \\
\hline
\end{tabular}


en consistently effective $(4,5,7)$. MTX, an important immunosuppressant, has been used in patients with scleredema. Although the mechanism of action of MTX in scleredema is unknown, it may suppress or down-regulate the production of fibroblasts or other cells involved with connective tissue or mucin production. Additionally, MTX may interfere with the above-mentioned glycation process (7). In 2005, Breuckmann et al. reported treatment failure in 7 cases diagnosed scleredema diabeticorum treated with an oral dose of $25 \mathrm{mg}$ MTX weekly (6). Van den Hoogen et al. (14) compared MTX with placebo in the treatment of systemic sclerosis and they found that all patients who received MTX for at least 24 weeks responded favourably to MTX therapy with reductions in skin thickness. However, Seyger et al. (7) described a case with severe scleredema diabeticorum partially treated with low dose MTX regimen. As confirmed in this report, in all patients, palpation and inspection showed substantial softening of former affected skin lesions as well as moderate histopathologic improvement, resulting in a partially response upon systemic low-dose MTX treatment.

In conclusion, the clinical and histological findings obtained from all of our patients demonstrate that MTX therapy may help to treat this rare disease. Further, larger cohort, long-term follow-up studies should be performed to define the role of low-dose MTX in scleredema diabeticorum.

\section{Conflict of Interest}

No conflict of interest was declared by the authors.

\section{References}

1. Beers WH, Ince A, Moore TL. Scleredema adultorum of Buschke: a case report and review of the literature. Semin Arthritis Rheum 2006;35:355-9. [CrossRef]

2. Engin B, Mat MC, Demirkesen C, Kotogyan A, Ozdogan H. Scleredema adultorum associated with hyperkeratosis. Pediatr Dermatol 2005;22:36-9. [CrossRef]
3. Turchin I, Adams SP, Enta T. Dermacase. Scleredema adultorum, or Bushke disease. Can Fam Physician 2003;49:1089-93.

4. Xiao T, Yang ZH, He CD, Chen HD. Scleredema adultorum treated with narrow-band ultraviolet B phototherapy. J Dermatol 2007;34:270-2. [CrossRef]

5. Kroft EB, de Jong EM. Scleredema diabeticorum case series: successful treatment with UV-A1. Arch Dermatol 2008;144:9478. [CrossRef]

6. Breuckmann F, Appelhans C, Harati A, Rotterdam S, Altmeyer $P$, Kreuter A. Failure of low-dose methotrexate in the treatment of scleredema diabeticorum in seven cases. Dermatology 2005;211:299-301. [CrossRef]

7. Seyger MM, van den Hoogen FH, de Mare S, van Haelst $U$, de Jong EM. A patient with a severe scleredema diabeticorum, partially responding to low-dose methotrexate. Dermatology 1999;198:177-9. [CrossRef]

8. Varga J, Gotta S, Li L, Sollberg S, Di Leonardo M. Scleredema adultorum: case report and demonstration of abnormal expression of extracellular matrix genes in skin fibroblasts in vivo and in vitro. Br J Dermatol 1995;132:992-9. [CrossRef]

9. Lewerenz $V$, Ruzicka T. Scleredema adultorum associated with type 2 diabetes mellitus: a report of three cases. J Eur Acad Dermatol Venereol 2007;21:560-1.

10. Meguerditchian $C$, Jacquet $P$, Béliard $S$, Benderitter $T$, Valéro $\mathrm{R}$, Carsuzza $\mathrm{F}$, et al. Scleredema adultorum of Buschke: an under recognized skin complication of diabetes. Diabetes Metab 2006;32:481-4. [CrossRef]

11. Ranganathan P. Infliximab-induced scleredema in a patient with rheumatoid arthritis. J Clin Rheumatol 2005;11:319-22. [CrossRef]

12. Angeli-Besson C, Koeppel MC, Jaquet $P$, Andrac L, Sayag J. Electronbeam therapy in scleredema adultorum with associated monoclonal hypergamma-blobulinemia. $\mathrm{Br} \mathrm{J}$ Dermatol 1994;130:394-7. [CrossRef]

13. Carrington PR, Sanusi ID, Winder PR, Turk LL, Jones C, Millikan LE. Scleredema adultorum. Int J Dermatol 1984;23:514-22. [CrossRef]

14. Van den Hoogen FH, Boerbooms AM, Swaak AJ, Rasker JJ, van Lier HJ, et al. Comparison of methotrexate with placebo in the treatment of systemic sclerosis: a 24 week randomized doubleblind trial, followed by a 24 week observational trial. Br J Rheumatol 1996;35:364-72. [CrossRef] 